\title{
Spur cell anaemia and hepatic iron stores in patients with alcoholic liver disease undergoing orthotopic liver transplantation
}

\author{
A Pascoe, P Kerlin, C Steadman, A Clouston, D Jones, L Powell, E Jazwinska, S Lynch, \\ R Strong
}

\begin{abstract}
Background-Following orthotopic liver transplantation (OLT) histological examination of explant livers from patients with alcoholic liver disease (ALD) sometimes shows extensive iron deposits in a distribution suggestive of homozygous haemochromatosis.

Aims-To use haemochromatosis gene (HFE) assays to distinguish between ALD with notable siderosis and hereditary haemochromatosis. To evaluate the possible influence of spur cell haemolytic anaemia on hepatic iron loading.

Patients-Thirty seven patients with ALD were abstinent for at least six months prior to OLT. Twenty three patients had transferrin saturations greater than $55 \%$, 16 also had increased serum ferritin $(>350$ $\mu \mathrm{g} / \mathrm{l})$. Eight of 37 (22\%) explant livers had grade 3 or 4 hepatic iron deposition, predominantly in hepatocytes. Of these, four had a hepatic iron index greater than 1.9 and most seemed to have spur cell haemolytic anaemia.

Methods-Mutation analysis for C282Y and H63D mutations was performed on DNA extracts from peripheral blood or explant liver. Spur cell haemolytic anaemia was diagnosed when the haemoglobin was $105 \mathrm{~g} / 1$ in the presence of notable acanthocytosis.

Results-None of the eight patients with grade 3 or 4 hepatic iron had evidence of the C282Y mutation. Two of the eight were heterozygous for H63D. None of the remaining 28 patients tested showed homozygous HFE mutations. Spur cell anaemia was present in six of the eight patients with heavy iron deposition and only one of the remaining patients.

Conclusions-The HFE mutation was not present in these patients with advanced ALD and heavy iron loading. Spur cell haemolytic anaemia provides an alternative potential mechanism for the heavy iron loading. (Gut 1999;45:301-305)
\end{abstract}

Keywords: alcoholic liver disease; haemochromatosis; hepatic iron index; orthotopic liver transplantation

Following orthotopic liver transplantation (OLT), histological examination of explant livers from patients with alcoholic liver disease (ALD) sometimes shows unexpectedly exten- sive iron deposits in a distribution suggestive of genetic homozygous haemochromatosis. Haemochromatosis is a common genetic disorder of iron metabolism inherited as an autosomal recessive trait. ${ }^{12}$ It is common among populations of Northern European descent with an estimated disease frequency of 1:300-400 and a carrier frequency of approximately $10 \%$. Excess hepatic iron deposition in homozygotes promotes cirrhosis and consequent liver failure. Typical liver histology, high hepatic iron index (HII), and positive family history have traditionally ${ }^{3}$ been used to diagnose genetic haemochromatosis and differentiate these patients from those with alcoholic siderosis. ${ }^{5}$ However, the accuracy and utility of HII in end stage cirrhosis is less clear, as there can be substantial variation in the values because of sampling error (fibrosis versus parenchyma)..$^{6-8}$

Patients with ALD selected for OLT frequently have poor hepatic reserve, coagulopathy, and ascites often precluding liver biopsy. Most transplant programmes require abstinence for at least six months pretransplant. Consequently explant histology is usually micronodular cirrhosis with no features to implicate or confirm an alcohol aetiology. Heavy iron deposits are not a characteristic feature.

Serum iron studies have a poor predictive capacity for separating homozygous haemochromatosis from alcoholic siderosis in which the serum ferritin is often elevated. ${ }^{9}{ }^{10}$ Iron studies can be influenced by clinical events. Bleeding from varices or portal hypertensive gastropathy may lead to iron depletion and confusion in the interpretation of iron studies that are borderline for haemochromatosis. In contrast, low total iron binding capacity and transferrin synthesis in chronic liver disease may artefactually elevate calculated transferrin saturation. Smith et $a l^{11}$ coined the term spur cell anaemia, describing a haemolytic anaemia with red cell morphology resembling acanthocytes in patients with alcoholic cirrhosis. True iron accumulation may occur in spur cell haemolytic anaemia due to increased iron absorption and the repeated blood transfusions.

The candidate gene for haemochromatosis, HFE C282Y mutation ${ }^{12}$ has been shown in

Abbreviations used in this paper: ALD, alcoholic liver disease; HFE, haemochromatosis gene; HII, hepatic iron index; OLT, orthotopic liver transplantation. 
pedigree family studies to have a clear association with haemochromatosis. ${ }^{13} 14$ Indeed, Jazwinska et $a l^{13}$ found that $100 \%$ of 112 white Australian patients with a positive family history of haemochromatosis were homozygous for the C282Y mutation. The second HFE mutation H63D is postulated to influence cellular iron homoeostasis. ${ }^{15} \mathrm{HFE}$ assays should allow distinction between alcoholic cirrhosis with notable siderosis and hereditary homozygous haemochromatosis.

Identification of haemochromatosis preoperatively is important as venesection may be feasible and beneficial, ${ }^{16}$ potentially reducing the perioperative risk of cardiac events and infection that have been reported in patients transplanted for haemochromatosis. ${ }^{17-19}$ In addition, accurate diagnosis in adults directs appropriate family screening, allowing detection of asymptomatic disease.

\section{Patients and methods}

Patients selected for this study were all those with a pre-OLT diagnosis of ALD. All patients had a history of chronic excessive alcohol intake ( $>50 \mathrm{~g} /$ day), but had been abstinent for at least the previous six months pre-OLT and had undergone routine assessment and evaluation by the Alcohol and Drug Dependency Unit as part of a standard protocol for liver transplantation (1985-96).

Past alcohol intake and pre-OLT serum iron concentration, total iron binding capacity, percentage transferrin saturation, and ferritin were recorded prospectively. Ferritin and transferrin were measured by chemiluminescence and immunoturbidimetry.

A single observer (AC) evaluated explant histology under code without knowledge of the clinical details, using routine light microscopy after formalin fixation. Sections were stained with haematoxylin and eosin and with Perls' Prussian blue stain. Data recorded included iron grading (0-4), ${ }^{20}$ the pattern and extent of iron deposition, and other histological features.

Explant liver iron concentration was measured by spectroscopy ${ }^{21}$ of a portion of representative liver removed from a paraffin wax block, and from this value hepatic iron index $(\mu \mathrm{mol}$ iron/g dry liver/age in years; abnormal >1.9) was calculated. Tissue analysed was predominantly parenchymal avoiding large areas of fibrosis. Sample size was $5 \times 5 \times$ $2 \mathrm{~mm}$.

Mutation analysis by genetic listing for both C282Y and H63D mutations was performed on DNA extracted from peripheral blood lymphocytes (29 patients) or tissue obtained from paraffin wax blocks from the explant liver (seven patients). ${ }^{22}{ }^{23}$ Spur cell haemolytic anaemia was diagnosed when the haemoglobin was not greater than $105 \mathrm{~g} / 1$ in the presence of notable acanthocytosis in the blood film. The need for blood transfusion was recorded.

\section{Results}

Of 243 adult patients (113 men) undergoing consecutive OLTs, 39 (32-66 years, 32 men)

Table 1 Preoperative and explant iron studies in 37 patients undergoing liver transplantation for alcoholic liver disease

\begin{tabular}{|c|c|c|c|c|c|c|c|c|c|c|}
\hline \multirow[b]{2}{*}{$\begin{array}{l}\text { OLT } \\
\text { number }\end{array}$} & \multicolumn{5}{|c|}{ Pretransplant } & \multicolumn{3}{|l|}{ Liver explant } & \multicolumn{2}{|c|}{ HFE analysis } \\
\hline & $\begin{array}{l}\text { Alcohol } \\
\text { (g/day) }\end{array}$ & $\begin{array}{l}\text { Child-Pugh } \\
\text { grade }\end{array}$ & $\begin{array}{l}\text { Transferrin } \\
\text { saturation * }\end{array}$ & $\begin{array}{l}\text { Serum } \\
\text { ferritint }\end{array}$ & $\begin{array}{l}\text { Spur cell } \\
\text { anaemia }\end{array}$ & $\begin{array}{l}\text { Histological iron } \\
\text { grade }(0-4)\end{array}$ & $\begin{array}{l}\text { Hepatic iron } \\
\text { concentration } \neq\end{array}$ & $\begin{array}{l}\text { Hepatic iron } \\
\text { indexs }\end{array}$ & $C 282 Y$ & $H 63 D$ \\
\hline 330 & 160 & C & 26 & 365 & $\mathrm{~N}$ & 0 & 19 & 0.29 & CC & $\mathrm{HH}$ \\
\hline 379 & 150 & C & 15 & 33 & $\mathrm{~N}$ & 0 & 14 & 0.48 & CC & $\mathrm{HH}$ \\
\hline 87 & 180 & C & 70 & 27 & $\mathrm{~N}$ & 0 & 21 & 0.50 & CC & $\mathrm{HH}$ \\
\hline 394 & 150 & B & 15 & 24 & $\mathrm{~N}$ & 0 & 6 & 0.09 & CC & $\mathrm{HH}$ \\
\hline 146 & 90 & C & 36 & 65 & $\mathrm{~N}$ & 0 & 17 & 0.30 & CC & HD \\
\hline 239 & 100 & C & 8 & 45 & $\mathrm{~N}$ & 0 & 8 & 0.20 & CY & $\mathrm{HH}$ \\
\hline 302 & 300 & C & 23 & 70 & $\mathrm{~N}$ & 0 & 6 & 0.10 & CC & HD \\
\hline 192 & 270 & B & 11 & 42 & $\mathrm{~N}$ & 0 & 4 & 0.08 & CC & $\mathrm{HH}$ \\
\hline 152 & 90 & C & 79 & 120 & $\mathrm{~N}$ & 0 & 7 & 0.13 & CC & $\mathrm{HH}$ \\
\hline 155 & 100 & C & 10 & 61 & $\mathrm{~N}$ & 0 & 15 & 0.25 & CC & HD \\
\hline 48 & 120 & C & 24 & 83 & $\mathrm{~N}$ & 0 & 6 & 0.12 & $\mathrm{CC}$ & $\mathrm{HH}$ \\
\hline 281 & 60 & C & 82 & 590 & $\mathrm{~N}$ & 0 & 24 & 0.49 & CC & $\mathrm{HH}$ \\
\hline 206 & 240 & C & 49 & 81 & $\mathrm{~N}$ & 0 & 7 & 0.17 & CC & HD \\
\hline 156 & 90 & B & 22 & 375 & $\mathrm{~N}$ & 1 & 41 & 0.82 & CC & $\mathrm{HD}$ \\
\hline 308 & 100 & B & 56 & 840 & $\mathrm{~N}$ & 1 & 18 & 0.45 & CY & HD \\
\hline 297 & 100 & C & 86 & 345 & $\mathrm{~N}$ & 1 & 12 & 0.25 & $\mathrm{CC}$ & $\mathrm{HH}$ \\
\hline 13 & 140 & C & 18 & 26 & $\mathrm{~N}$ & 1 & 7 & 0.14 & CC & $\mathrm{HH}$ \\
\hline 365 & 140 & C & 80 & 230 & $\mathrm{~N}$ & 1 & 55 & 1.34 & CC & $\mathrm{HH}$ \\
\hline 225 & 100 & C & 70 & 590 & $\mathrm{~N}$ & 1 & 68 & 1.24 & CC & $\mathrm{HH}$ \\
\hline 299 & 100 & C & 70 & 1090 & $\mathrm{~N}$ & 1 & 30 & 0.67 & CC & $\mathrm{HH}$ \\
\hline 207 & 100 & C & 70 & 315 & $\mathrm{~N}$ & 1 & 30 & 0.71 & - & - \\
\hline 388 & 50 & C & 73 & 590 & $\mathrm{~N}$ & 1 & 43 & 0.95 & CC & HD \\
\hline 223 & 140 & C & 63 & 550 & $\mathrm{~N}$ & 1 & 57 & 0.97 & CC & $\mathrm{HH}$ \\
\hline 341 & 180 & C & 79 & 430 & $\mathrm{~N}$ & 1 & 40 & 0.95 & CC & $\mathrm{HH}$ \\
\hline 198 & 100 & C & 66 & 800 & $\mathrm{~N}$ & 2 & 39 & 0.79 & CC & $\mathrm{HH}$ \\
\hline 167 & 200 & B & 38 & 280 & $\mathrm{~N}$ & 2 & 61 & 1.10 & CC & $\mathrm{HD}$ \\
\hline 370 & 100 & C & 74 & 390 & $\mathrm{Y}$ & 2 & 30 & 0.58 & CC & $\mathrm{HH}$ \\
\hline 278 & 90 & C & 77 & 200 & $\mathrm{~N}$ & 2 & 29 & 0.56 & CC & $\mathrm{HH}$ \\
\hline 50 & 180 & C & 84 & 730 & $\mathrm{~N}$ & 2 & 27 & 0.59 & CC & $\mathrm{HH}$ \\
\hline 425 & 90 & B & 62 & 330 & $\mathrm{~N}$ & 3 & 88 & 1.95 & $\mathrm{CC}$ & $\mathrm{HD}$ \\
\hline 373 & 150 & C & 44 & 365 & $\mathrm{~N}$ & 3 & 102 & 2.54 & CC & $\mathrm{HH}$ \\
\hline 392 & 80 & C & 74 & 510 & $\mathrm{Y}$ & 3 & 130 & 1.87 & CC & $\mathrm{HH}$ \\
\hline 432 & 110 & C & 97 & 2980 & $\mathrm{Y}$ & 4 & 54 & 1.35 & CC & $\mathrm{HH}$ \\
\hline 276 & 200 & C & 87 & 1036 & $\mathrm{Y}$ & 4 & 55 & 0.93 & CC & $\mathrm{HH}$ \\
\hline 296 & 180 & C & 84 & 1380 & $\mathrm{Y}$ & 4 & 95 & 1.70 & CC & $\mathrm{HH}$ \\
\hline 401 & 120 & C & 76 & 1200 & $\mathrm{Y}$ & 4 & 170 & 3.40 & CC & $\mathrm{HD}$ \\
\hline 313 & 110 & C & 84 & 1775 & $\mathrm{Y}$ & 4 & 232 & 5.10 & CC & $\mathrm{HH}$ \\
\hline
\end{tabular}

Normal values: ${ }^{\star} 15-55 \%$; $† 25-350 \mu \mathrm{l} ; \ddagger<25 \mu \mathrm{mol} / \mathrm{g} ; \mathbb{\$}<2$.

HFE: C282Y gene mutation (CC = homozygous normal, $\mathrm{CY}=$ heterozygous); H63D gene mutation $(\mathrm{HH}=$ homozygous normal, $\mathrm{HD}=$ heterozygous). 

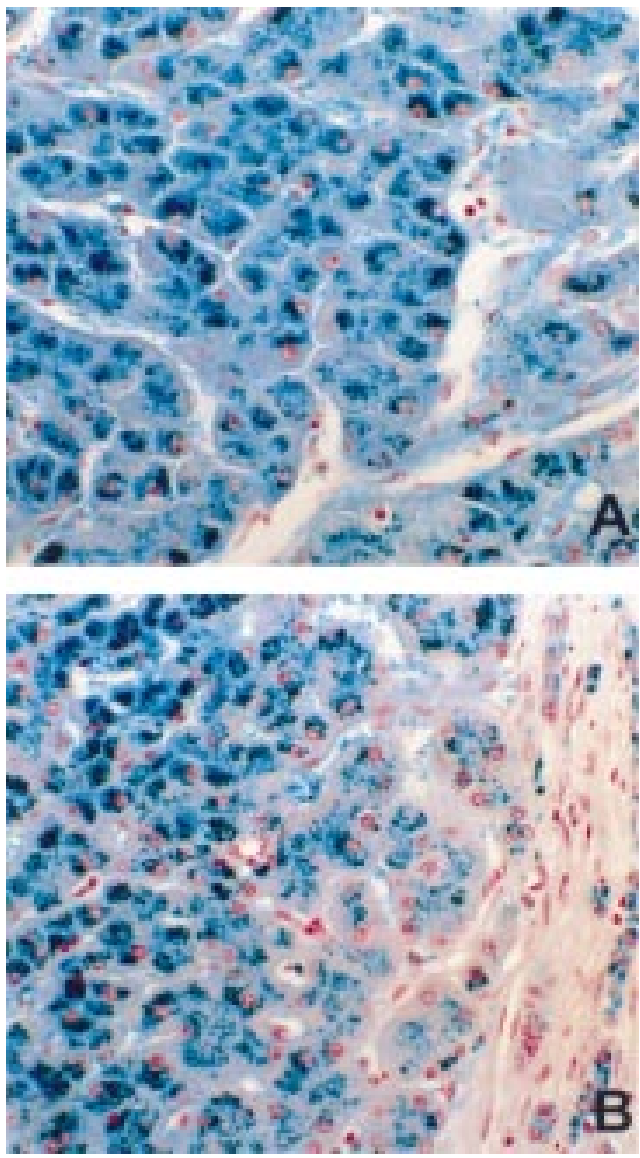

Figure 1 Grade 4 siderosis in two patients with alcoholic liver disease and spur cell anaemia, showing predominantly hepatocyte deposition. Patients OLTX $313(A)$ and OLTX 392 (B) are homozygous normal for the C282Y and H63D mutations and have no family history of haemochromatosis. Both have spur cell anaemia. (Perls' stain; original magnification $\times 250$ ).

had a prior heavy alcohol intake. Two were excluded from this study because they had severe acute alcoholic hepatitis. Thirty six patients were white, one was Japanese. Thirty one were Child-Pugh class $\mathrm{C}$ and six were class B (table 1). Seven were hepatitis C antibody (anti-HCV) positive. The median alcohol consumption was $120 \mathrm{~g}$ per day with only three of 37 consuming more than $90 \mathrm{~g} /$ day and no patients regularly consuming less than 50 g/day. The median transferrin saturation was $70 \%$ with a range $10-97 \%$ (normal range

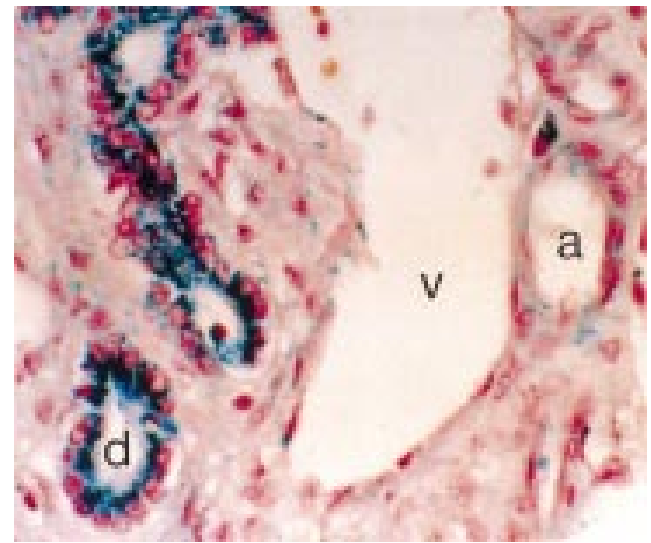

Figure 2 Deposition of iron in bile duct epithelium (d) and arteriolar walls (a) in a patient (OLTx 401) with spur cell anaemia and normal C282Y and heterozygous H63D gene analysis (Perls'stain; original magnification $\times$ 400). v, vein.

15-55\%). The median serum ferritin was 365 $\mu \mathrm{g} / \mathrm{l}$ with a range $24-2980 \mu \mathrm{g} / \mathrm{l}$ (normal range $25-350 \mu \mathrm{g} / \mathrm{l})$.

Twenty eight patients had a liver biopsy pretransplant, 10 by the transjugular route and the remainder by percutaneous intercostal Tru-cut biopsy. Only three of these patients had biopsies with grade 3 or 4 iron (patients 296, 392, 432). Explant histology showed micronodular cirrhosis in 36 patients and severe fibrosis in one. Two patients had Mallory's hyaline. Eleven explants showed mild chronic active hepatitis and two had portal lymphoid aggregates (both patients were anti-HCV positive). Twenty nine explants had either no iron at all or iron deposits in Kupffer cells with only mild hepatocyte depositions (table 1). Eight had grade 3 or 4 iron stores on examination of the explant liver. Six of these showed significant iron deposition in bile ducts and blood vessels in addition to that seen in hepatocytes and Kupffer cells (figs 1 and 2). None of this group was anti-HCV positive. Some patients with grade 1 or 2 iron had relatively high iron concentrations, at levels similar to those with grade 3 or 4 iron staining. This is likely a reflection of sampling.

None of the 36 patients tested, including the eight subjects with grade 3 or 4 iron, were homozygous for the C282Y mutation. Two subjects $(239,308)$ were heterozygous but had insignificant iron concentrations. None of the

Table 2 Patients with grade 3 or 4 iron staining (explant liver)

\begin{tabular}{|c|c|c|c|c|c|c|c|c|c|c|}
\hline \multirow[b]{2}{*}{$\begin{array}{l}\text { OLT } \\
\text { number }\end{array}$} & \multicolumn{5}{|l|}{ Pretransplant } & \multicolumn{3}{|l|}{ Explant } & \multicolumn{2}{|c|}{ HFE analysis } \\
\hline & $\begin{array}{l}\text { Histological iron } \\
\text { grade I }(0-4)\end{array}$ & $\begin{array}{l}\text { Transferrin } \\
\text { saturation * }\end{array}$ & $\begin{array}{l}\text { Serum } \\
\text { ferritint }\end{array}$ & $\begin{array}{l}\text { Spur cell } \\
\text { haemolytic } \\
\text { anaemia }\end{array}$ & $\begin{array}{l}\text { Units transfused } \\
\text { before surgery }\end{array}$ & $\begin{array}{l}\text { Histological } \\
\text { iron grade I } \\
(0-4)\end{array}$ & $\begin{array}{l}\text { Hepatic iron } \\
\text { concentration } \neq\end{array}$ & $\begin{array}{l}\text { Hepatic } \\
\text { iron indexs }\end{array}$ & $C 282 Y$ & $H 63 D$ \\
\hline 425 & - & 62 & 330 & No & - & 3 & 88 & 1.95 & CC & HD \\
\hline 373 & - & 44 & 365 & No & - & 3 & 102 & 2.54 & CC & $\mathrm{HH}$ \\
\hline 392 & $2^{\star \star}$ & 74 & 510 & Yes & 2 & $3(2-3+)$ & 130 & 1.87 & CC & $\mathrm{HH}$ \\
\hline 432 & $4^{\star \star}$ & 97 & 2980 & Yes & 4 & 4 & 54 & 1.35 & $\mathrm{CC}$ & $\mathrm{HH}$ \\
\hline 276 & - & 87 & 1036 & Yes & - & $4(2-4)$ & 55 & 0.93 & CC & $\mathrm{HH}$ \\
\hline 296 & $3^{\star \star}$ & 84 & 1380 & Yes & 10 & $4(2-4)$ & 95 & 1.70 & $\mathrm{CC}$ & $\mathrm{HH}$ \\
\hline 401 & 2 & 76 & 1200 & Yes & 4 & $4(3-4)$ & 170 & 3.40 & $\mathrm{CC}$ & $\mathrm{HD}$ \\
\hline 313 & - & 84 & 1775 & Yes & 17 & $4(3-4)$ & 232 & 5.10 & $\mathrm{CC}$ & $\mathrm{HH}$ \\
\hline
\end{tabular}

Normal values: ${ }^{\star} 15-55 \%$; †25-350 $\mu \mathrm{l} ; \ddagger<25 \mu \mathrm{mol} / \mathrm{g} ; \S<1.9$.

${ }^{\star \star}$ Transjugular liver biopsy.

HFE: C282Y gene mutation (CC = homozygous normal); H63D gene mutation ( $\mathrm{HH}=$ homozygous normal, $\mathrm{HD}=$ heterozygous).

$\mathrm{HII}$, hepatic iron index ( $\mu \mathrm{mol} / \mathrm{g}$ dry weight/age in years). ${ }^{3}$

I, histological assessment. ${ }^{20}$ 
36 patients tested were homozygous for the H63D mutation. Ten patients were heterozygous for the H63D mutation and patient 308 was a complex heterozygote with normal iron stores.

Table 2 presents expanded details of the eight patients with grade 3 or 4 iron deposits in the explant liver. As noted there was some variability in the intensity of iron deposits in different areas of the liver. All had elevated hepatic iron concentrations. The HII exceeded 1.9 in four patients. Spur cell haemolysis was observed pre-OLT in six patients, five of whom were blood transfusion dependent. They had received 2-17 units of blood. Post-transplant, the anaemia and acanthocytosis resolved by a maximum of 20 days. Spur cell haemolysis was noted in only one of the remaining 29 patients (patient 370, histological iron grade 2, normal hepatic iron concentration).

\section{Discussion}

Although it has long been regarded that heavy siderosis in patients with ALD is likely to reflect coexisting genetic haemochromatosis ${ }^{24} 25$ this study shows that the haemochromatosis gene mutation was not present in our patients with heavy iron loading. Approximately $20 \%$ of our abstinent alcoholic patients had grade 3 or 4 iron stores in the explant liver. The iron was distributed widely in a pattern indistinguishable from that seen in homozygous haemochromatosis. The HII has been used successfully to predict genetic iron overload but not in the subgroup of patients with end stage liver disease. Random liver biopsy specimens taken from different parts of a cirrhotic liver can yield highly variable HIIs. ${ }^{6}$ Although these results would suggest that several of the patients had genetic haemochromatosis, genetic testing showed that no patient had evidence of the C282Y mutation.

Most of the patients with heavy iron deposition in this study had spur cell haemolytic anaemia and required transfusions prior to OLT. In spur cell haemolysis erythrocytes develop an abnormal lecithin/phospholipid ratio in the cell membrane causing acanthocytosis and spurring with a multispiculated cell membrane. ${ }^{26}$ This promotes splenic destruction of affected erythrocytes and consequently shortens survival for both native and transfused cells. ${ }^{27}{ }^{28}$ It is a poor prognostic marker for patients with liver disease. Intestinal iron absorption is increased in haemolytic states and repeated blood transfusions also promote secondary iron overload in the liver. ${ }^{29}$

The dominant deposition of tissue iron in hepatocytes and proliferating bile ducts and not in the reticuloendothelial cells suggests that the chief mechanism of iron loading may be enhanced mucosal absorption associated with accelerated erythropoiesis rather than transfusional iron. ${ }^{29}$ As this enhanced mucosal uptake mimics the mechanism of accumulation in genetic haemochromatosis it is not surprising that the histological appearances overlap.

We have shown that none of the patients with grade 3 or 4 iron in the explant liver has genetic homozygous haemochromatosis. Two patients were heterozygous for the H63D mutation in the HFE gene. Although this mutation may have some influence on secondary iron overload it was also present in several patients with insignificant iron loading. The histological appearance in the eight patients with alcoholic siderosis mimics findings in genetic iron overload. Spur cell haemolysis was observed pre-OLT in the majority of these patients and may explain the observed hepatic iron loading. Post-OLT, spur cell anaemia resolved.

Many of the liver transplant patients in various transplant centres previously assessed as having genetic haemochromatosis on the basis of explant histology and iron quantification without the HFE assay are possibly cases of ALD and not hereditary haemochromatosis. We have shown that a likely cause of the gross iron loading in end stage alcoholic liver disease is haemolysis due to spur cell anaemia. Whether the prognosis of such patients after OLT differs from patients with HFE associated haemochromatosis (treated or untreated) remains to be established.

The authors express their thanks to Lesa Summerville and Anne Pink for technical assistance in the genetic studies.

1 Simon M, Bourel M, Genetet B, et al. Idiopathic haemochromatosis: demonstration of recessive transmission and early detection by family HLA typing. $N$ Engl 7 sion and early detection

2 Cartwright GE, Edwards CQ, Kraritz K, et al. Hereditary haemochromatosis: phenotypic expression of the disease. $N$ Engl f Med 1979;301:175-9.

3 Bassett ML, Halliday JW, Powell LW. Value of hepatic iron measurements in early haemochromatosis and determination of the critical iron level associated with fibrosis. Hepatology 1986;6:24-9.

4 Summers KM, Halliday JW, Powell LW. Identification of homozygous haemochromatosis subjects by measurement of hepatic iron index. Hepatology 1990;12:20-5.

5 Powell LW, Fletcher LM, Halliday JW. Distinction between haemochromatosis and alcoholic siderosis. In: Hall P, ed. Alcoholic liver disease, pathology and pathogenesis. London: Alcoholic liver disease, pathology and

6 Villeneuvre J-P, Bilodeau M, LePage R, et al. Variability in hepatic iron concentration measurement from needle biopsy specimens. F Hepatol 1996;25:172-7.

7 Ambu R, Crisponi G, Sciot R, et al. Uneven hepatic iron and phosphorous distribution in beta-thalassemia. 7 Hepatol 1995;23:544-9

8 Ludwig J, Hashimoto E, Porayko M, et al. Haemosiderosis in cirrhosis: a study of 447 native livers. Gastroenterology 1997;112:882-8.

9 Bonkovsky HL, Slaker D, Bills E, et al. Usefulness and limitations of laboratory and hepatic imaging studies in iron-storage disease. Gastroenterology 1990;99:1080-91.

10 Chapman RW, Morgan MY, Laulicht M, et al. Hepatic iron stores and markers of iron overload in alcoholics and patients with idiopathic haemochromatosis. Dig Dis $S_{c i}$ 1982;27:909-16.

11 Smith JA, Lonergan ET, Sterling K. Hemolytic anaemia with red cells resembling acanthocytes in alcoholic cirrhosis. N Engl f Med 1964;271:396.

12 Feder JN, Gnirke A, Thomas W, et al. A novel MHC class 1-like gene is mutated in patients with hereditary 1-like gene is mutated in patients with

13 Jazwinska EC, Cullen EM, Busfield F, et al. Haemochromatosis and HLA-H. Nat Genet 1996;14:249-51.

14 Jouanolle AM, Gandon G, Jezequel P, et al. Haemochromatosis and HLA-H. Nat Genet 1996;14:251-2.

15 Feder JN, Penny D, Irrinki A, et al. The hemochromatosis gene product complexes with the transferrin receptor and owers its affinity for ligand binding. Proc Natl Acad Sci USA 1998;95:1472-7.

16 Niederau C, Fischer R, Sonnenberg A, et al. Survival and causes of death in cirrhotic and non-cirrhotic patients with primary haemochromatosis. N Engl f Med 1985;313:125662.

17 Kilpe VE, Krakauer H, Wren RE. An analysis of liver transplant experience from 37 transplant centres as reported to plant experience from 37 transplant centres

18 Farrell FJ, Nguyen M, Woodley S, et al. Outcome of liver transplantation in patients with haemochromatosis. Hepatology 1994;20:404-10. 
19 Poulos JE, Bacon BR. Liver transplantation for hereditary haemochromatosis. Dig Dis Sci 1996;14:316-22.

20 Searle J, Kerr JFR, Halliday JW, et al. Iron storage disease. In: MacSween RNM, Anthony PP, Scheuer PJ, et al, eds. Pathology of the liver. 3rd edn. Churchill Livingstone, 1994 219-41.

21 Barry M, Sherlock S. Measurement of liver-iron concentration in needle-biopsy specimens. Lancet 1971;i:100-3.

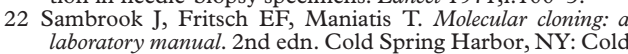
Spring Harbor Laboratory Press, 1989.

23 Cullen LM, Gao X, Easteal S, et al. The hemochromatosis 845 G-A and 187 C-G mutations: prevalence in nonCaucasian populations. Am f Hum Genet 1998;62:1403-7.

24 Adams PC, Bradley C, Henderson AR. Evaluation of the hepatic iron index as a diagnostic criterion for genetic haemochromatosis. f Lab Clin Med 1997;130:509-14.
25 Deugnier Y, Turlin B, le Quilleuc D, et al. A reappraisal of hepatic siderosis in patients with end-stage cirrhosis: pracAm f Surg Pathol 1977;21:669-75.

26 Cooper RA, Diloy-Puray M, Lando P, et al. An analysis of lipoproteins, bile acids, and red cell membranes associated with target cells and spur cells in patients with liver disease. f Clin Invest 1972;51:3182-92.

27 Cooper RA, Kimball DB, Durocher JR. Role of the spleen in membrane conditioning and hemolysis of spur cells in liver disease. N Engl F Med 1974;290:1279-84.

28 Silber R, Amorsi E, Lhowe J, et al. Spur-shaped erythrocytes in Laennec's cirrhosis. N Engl F Med 1966;275:639-43.

29 Powell LW, Jazwinska E, Halliday JW, Primary iron overload. In: Brock JH, Halliday JW, Pippard MJ, Powell LW, eds. Iron metabolism in health and disease. London: WB Saunders, 1994:227-70. 